\title{
PEMANFAATAN APLIKASI ANDROID BABY CARE SEBAGAI SOLUSI DALAM PENCATATAN TUMBUH KEMBANG ANAK
}

\author{
Mariza Devega*1, Fana Wiza ${ }^{2}$ \\ ${ }^{1}$ Program Studi Teknik Informatika, Fakultas Ilmu Komputer, Universitas Lancang Kuning \\ ${ }^{2}$ Program Studi Sistem Informasi, Fakultas Ilmu Komputer, Universitas Lancang Kuning \\ Jl. Yos sudarso km 8 Rumbai Pekanbaru Riau \\ e-mail: marizadevega@unilak.ac.id
}

\begin{abstract}
The use of Smart Phone Android today is not only as a supporter of communication between humans, but also can be used like a laptop that is usually used in terms of searching for information, read news, and so forth. Baby care is an android application that serves to see the baby's record, ranging from growing flowers, vaccination, nutritional intake, milk, sleep duration and so on, besides this application replaces the manual recording function that is prone to damage and lost (Human eror). Training This application aims to facilitate the mothers in seeing their children grow more detailed in effective and efficient, and at the same time replace the previous function which record manually.
\end{abstract}

Keywords : Android Application, Baby Care, KMS

\begin{abstract}
Abstrak
Penggunaan Smart Phone Android saat ini tidak hanya sebagai penunjang komunikasi antar manusia, tetapi juga dapat digunakan layaknya laptop yang biasanya digunakan dalam hal mencari informasi, membaca berita, dan lain sebagainya. Baby care adalah sebuah aplikasi android yang berfungsi untuk melihat record bayi, mulai dari tumbuh kembangnya, vaksinasi, asupan gizi, susu, durasi tidur dan lain sebagainya, selain itu aplikasi ini menggantikan fungsi pencatatan secara manual yang rawan dari kerusakan dan hilang (Human eror). Pelatihan Aplikasi ini bertujuan untuk memudahkan ibu-ibu dalam melihat tumbuh kembang anaknya dengan lebih terinci efektif dan efisien serta sekaligus menggantikan fungsi pencatatan sebelumnya yang dilakukan secara manual.
\end{abstract}

Kata kunci : Aplikasi android, Baby Care, KMS

\section{PENDAHULUAN}

$\mathrm{P}$ erkembangan ini adalah template untuk versi Word (doc). Bila anda dapat menggunakan versi dokumen ini sebagai referensi untuk menulis manuscript anda. Teknologi memiliki dampak positif maupun dampak negatif. Dampak-dampak tersebut tentunya berpengaruh dalam berbagai sektor kehidupan. Penggunaan Smart Phone Android saat ini tidak hanya sebagai penunjang komunikasi antar manusia, tetapi juga dapat digunakan layaknya laptop yang biasanya digunakan dalam hal mencari informasi, membaca berita, dan lain sebagainya. Banyak aplikasi yang di tawarkan pada smart phone android, baik aplikasi hiburan maupun aplikasi yang diperuntukkan untuk memudahkan pengguna dalam hal-hal tertentu.

Baby care adalah sebuah aplikasi android yang berfungsi untuk melihat record bayi, mulai dari tumbuh kembangnya, vaksinasi, asupan gizi, susu, durasi tidur dan lain sebagainya, selain itu aplikasi ini menggantikan fungsi pencatatan secara manual yang biasanya dicatat dikertas. Mengingat manfaat yang ada aplikasi ini oleh karena itu dilakukanlah sosialisai aplikasi Baby Care ini bagi ibu-ibu yang ada di Posyandu kelurahan Sukamaju kecamatan Sail. Dengan adanya pelatihan ini diharapkan memudahkan ibu-ibu dalam melihat record dan perkembangan bayi mereka dari waktu ke waktu, serta menggantikan pencatatan manual yang rentan hilang dan rusak oleh karena satu dan lain hal. 
Aplikasi ini bertujuan untuk memudahkan ibu-ibu dalam melihat tumbuh kembang anaknya dengan lebih terinci efektif dan efisien.

Oleh karena itu, pada pengabdian ini diangkat sebuah tema tentang sosialisasi aplikasi ini bertujuan untuk memudahkan ibu-ibu dalam melihat tumbuh kembang anaknya dengan lebih terinci efektif dan efisien.

Menurut Nasruddin Safaat h (Pemrograman aplikasi mobile smartphone dan tablet PC berbasis android 2012:1) android adalah sebuah sistem operasi pada handphone yang bersifat terbuka dan berbasis pada sistem operasi Linux. Android bisa digunakan oleh setiap orang yang ingin menggunakannya pada perangkat mereka. Android menyediakan platform terbuka bagi para pengembang untuk menciptakan aplikasi mereka sendiri yang akan digunakan untuk bermacam peranti bergerak. Awalnya, Google Inc. membeli Android Inc., pendatang baru yang membuat peranti lunak untuk ponsel. Kemudian untuk mengembangkan Android, dibentuklah Open Handset Alliance, konsorsium dari 34 perusahaan peranti keras, peranti lunak, dan telekomunikasi, termasuk Google, HTC, Intel, Motorola, Qualcomm, T-Mobile, dan Nvidia. Pada saat perilisan perdana Android, 5 November 2007,Android bersama Open Handset Alliance menyatakan mendukung pengembangan standar terbuka pada perangkat seluler. Di lain pihak, Google merilis kode-kode Android di bawah lisensi Apache, sebuah lisensi perangkat lunak dan standar terbuka perangkat seluler.

a. Kelebihan Android

1. Multitasking - Kalau anda pernah merasakan keunggulan dari Symbian yang bisa membuka beberapa aplikasi sekaligus, begitu juga Android yang mampu membuka beberapa aplikasi sekaligus tanpa harus menutup salah satunya.

2. Kemudahan dalam Notifikasi - Setiap ada SMS, Email, atau bahkan artikel terbaru dari RSS Reader, akan selalu ada notifikasi di Home Screen Ponsel Android, tak ketinggalan Lampu LED Indikator yang berkedip-kedip, sehingga Anda tidak akan terlewatkan satu SMS, Email ataupun Misscall sekalipun.

3. Akses Mudah terhadap Ribuan Aplikasi Android lewat Google Android App Market Kalau Anda gemar install aplikasi ataupun games, lewat Google Android App Market Anda bisa mendownload berbagai aplikasi dengan gratis. Ada banyak ribuan aplikasi dan games yang siap untuk Anda download di ponsel Android.

4. Pilihan Ponsel yang beranekaragam - Bicara ponsel Android, akan terasa „beda "dibandingkan dengan iOS, jika iOS hanya terbatas pada iPhone dari Apple, maka Android tersedia di ponsel dari berbagai produsen, mulai dari Sony Ericsson, Motorola, HTC sampai Samsung.

Setiap pabrikan ponsel pun menghadirkan ponsel Android dengan gaya masing-masing, seperti Motorola dengan Motoblur-nya, Sony Ericsson dengan TimeScape-nya. Jadi Anda bisa leluasa memilih ponsel Android sesuai dengan „,merk ${ }^{e c}$ favorite.

5. Bisa menginstal ROM yang dimodifikasi - tak puas dengan tampilan standar Android, jangan khawatir ada banyak Costum ROM yang bisa Anda pakai di ponsel Android.

6. Widget - benar sekali, dengan adanya Widget di homescreen, Anda bisa dengan mudah mengakses berbagai setting dengan cepat dan mudah.

7. Google Maniak - Kelebihan Android lainnya jika Anda pengguna setia layanan Google mulai dari Gmail sampai Google Reader, ponsel Android telah terintegrasi dengan layanan Google, sehingga Anda bisa dengan cepat mengecek email dari Gmail.

b. Kelemahan Android

1. Koneksi Internet yang terus menerus - Yups, kebanyakan ponsel berbasis system ini memerlukan koneksi internet yang simultan alias terus menerus aktif.Koneksi internet GPRS selalu aktif setiap waktu, itu artinya Anda harus siap berlangganan paket GPRS yang sesuai dengan kebutuhan.

2. Iklan - Aplikasi di Ponsel Android memang bisa didapatkan dengan mudah dan gratis, namun konsekuensinya di setiap Aplikasi tersebut, akan selalu Iklan yang terpampang, entah itu bagian atas atau bawah aplikasi. 


\section{METODE}

Metode pelaksanaan pengabdian ini adalah dengan mengadakan pelatihan tentang pengenalan aplikasi Baby care :

1. Tahap pertama yaitu fase penyuluhan, setiap peserta akan diberikan pengarahan terlebih dahulu mengenai manfaat serta keunggulan aplikasi mobile phone yaitu baby care.

2. Tahap kedua yaitu fase demonstrasi dan pelatihan (praktek). Setiap peserta akan diberikan modul untuk memudahkan berlangsungnya pelatihan dengan materi berikut :

a. Instalasi aplikasi pada smart phone

b. Pengenalan Baby Care

c. Pengenalan Fitur yang tersedia

d. Penggunaan

3. Tahap ketiga yaitu fase evaluasi, evaluasi yang dilakukan pada kegiatan ini meliputi :

a. Evaluasi proses, dilakukan pada saat kegiatan sedang berlangsung. Aktivitas yang dievaluasi adalah dari minat peserta untuk melakukan tanya jawab dan diskusi mengenai tema pelatihan yang disajikan.

b. Evaluasi hasil, dilakukan dengan meminta peserta mencoba melakukan sendiri baik dalam hal memasukkan data anak sampai kepada pemanfaatkan fitur-fitur yang tersedia pada aplikasi Baby Care.

c. Pada akhir kegiatan setiap peserta akan diberikan kuesioner untuk diisi sebagai evaluasi tim pengabdi di tahap akhir dan sebagai indikator keberhasilan dari pelatihan yang telah dilakukan.

\section{HASIL DAN PEMBAHASAN}

Kegiatan pengabdian ini dilaksanakan pada hari jumat 5 Mei 2017 yang bertempat di posyandu RT/RW 004/005 dengan memajang banner kegiatan yang menandakan adanya kegiatan pengabdian pada masyarakat yang sedang berlangsung. Kegiatan ini dimulai pada pukul 09.00 sampai dengan pukul 11.30 WIB dengan diikuti 13 orang peserta. Setiap peserta sosialisasi diberikan modul tata cara penggunaan aplikasi Baby Care untuk memandu peserta dalam penggunaan aplikasi baby care tersebut.

Pada awal kegiatan pemateri menjelaskan dan memperkenalkan Baby Care serta memaparkan tentang kegunaannya. Selanjutnya pemateri melakukan demonstrasi penggunaan aplikasi Baby Care dimana didalamnya termasuk input data dari masing-masing fitur yang tersedia, seperti data bayi termasuk didalamnya tanggal lahir, berat badan lahir, panjang badan dan seterusnya. Kemudian input jenis-jenis vaksin yang sudah diberikan, input perkembangan berat badan, tinggi badan dan lain-lain. Setelah itu pemateri juga menjelaskan bagaimana membaca grafik dari perkembangan bayi dan balita.

Pada akhir penelitian peserta diberikan kuisioner sebelum awal pelatihan dan setelah dilakukannya pelatihan, hal ini bertujuan untuk mengukur sejauh mana keberhasilan dari pelaksanaan pengabdian ini. Kuisioner yang di berikan kepada peserta menggunakan skala Guttman. Yaitu skala yang menginginkan tipe jawaban tegas, seperti jawaban benar-salah, yatidak, pernah-tidak pernah, positive-negative, tinggi-rendah, baik-buruk dan seterusnya. Pada skala Guttman hanya ada dua interval, yaitu setuju dan tidak setuju. Skala Guttman dapat dibuat dalam bentuk pilihan ganda ataupun checklist. Untuk jawaban positif seperti benar, ya, tinggi, baik dan semacamnya diberi skor 1 , sedangkan untuk jawaban negative seperti salah, buruk, rendah, tidak dan semacamnya diberi skor 0 . 
Table 5.1 Kuisioner Tahap Awal

\begin{tabular}{|l|l|c|c|c|c|c|c|c|c|}
\hline No & Responden & P1 & P2 & P3 & P4 & P5 & P6 & P7 & P8 \\
\hline 1. & SRI ROSMIATI & 1 & 0 & 1 & 0 & 0 & 0 & 0 & 0 \\
\hline 2. & HELPRIDA & 0 & 0 & 0 & 0 & 0 & 0 & 0 & 0 \\
\hline 3. & SAINAM & 0 & 0 & 0 & 0 & 0 & 0 & 0 & 0 \\
\hline 4. & WIDIA & 0 & 0 & 0 & 0 & 0 & 0 & 0 & 0 \\
\hline 5. & YUNI & 0 & 0 & 0 & 0 & 0 & 0 & 0 & 0 \\
\hline 6. & IKA & 0 & 0 & 0 & 0 & 0 & 0 & 0 & 0 \\
\hline 7. & MARIET SENJA & 1 & 1 & 1 & 0 & 0 & 0 & 0 & 1 \\
\hline 8. & DESI SURYANI & 1 & 0 & 1 & 0 & 0 & 0 & 0 & 0 \\
\hline 9. & LILIS & 0 & 0 & 0 & 0 & 0 & 0 & 0 & 0 \\
\hline 10. & EPI LIANA & 0 & 0 & 0 & 0 & 0 & 0 & 0 & 0 \\
\hline 11. & EKA HERYANI & 0 & 0 & 0 & 0 & 0 & 0 & 0 & 0 \\
\hline 12. & SITI & 0 & 0 & 0 & 0 & 0 & 0 & 0 & 0 \\
\hline 13 & YATI & 0 & 0 & 0 & 0 & 0 & 0 & 0 & 0 \\
\hline & & 3 & 3 & 3 & 0 & 0 & 0 & 0 & 1 \\
\hline
\end{tabular}

Keterangan: P1 sampai dengan P8 adalah pertanyaan yang ada pada kuisioner dimulai dengan pert nyaan P1 sebagai pertanyaan pertama, P2 pertayaan kedua dan seterusnya sampai dengan P9.

Table 5.2 Perhitungan Presentase Pengetahuan Responden Sebelum Pelatihan

\begin{tabular}{|c|c|c|}
\hline Item Pertanyaan & Total Jawab Ya & (\%) Jawaban Ya \\
\hline P1 & 3 & 42,86 \\
\hline P2 & 1 & 14,28 \\
\hline P3 & 3 & 42,86 \\
\hline P4 & 0 & 0,00 \\
\hline P5 & 0 & 0,00 \\
\hline P6 & 0 & 0,00 \\
\hline P7 & 0 & 0,00 \\
\hline P8 & 0 & 0,00 \\
\hline Total & 7 & 100 \\
\hline Rata-Rata & 0.875 & 12.5 \\
\hline
\end{tabular}

Perhitungan jawaban "ya" dari angket :

Sehingga persentase jawaban "ya" adalah 12,5\%

Pengetahuan awal : $12,5 \%$

Table 5.3. Total Jawaban Responden

\begin{tabular}{|l|l|l|l|l|l|l|l|l|l|}
\hline No & Responden & P1 & P2 & P3 & P4 & P5 & P6 & P7 & P8 \\
\hline 1 & SRI ROSMIATI & 1 & 1 & 1 & 1 & 1 & 1 & 1 & 1 \\
\hline 2 & HELPRIDA & 1 & 1 & 1 & 1 & 1 & 1 & 1 & 1 \\
\hline 3 & SAINAM & 1 & 1 & 1 & 1 & 1 & 1 & 1 & 0 \\
\hline 4 & WIDIA & 1 & 1 & 1 & 1 & 1 & 1 & 1 & 1 \\
\hline 5 & YUNI & 1 & 1 & 1 & 1 & 1 & 1 & 1 & 0 \\
\hline 6 & IKA & 1 & 1 & 1 & 1 & 0 & 1 & 1 & 0 \\
\hline 7 & MARIET SENJA & 1 & 1 & 1 & 1 & 1 & 1 & 1 & 1 \\
\hline 8 & DESI SURYANI & 1 & 1 & 1 & 1 & 1 & 1 & 1 & 1 \\
\hline 9 & LILIS & 1 & 1 & 1 & 0 & 0 & 1 & 1 & 0 \\
\hline 10 & EPI LIANA & 1 & 1 & 1 & 0 & 0 & 0 & 1 & 0 \\
\hline 11 & EKA HERYANI & 1 & 1 & 1 & 1 & 1 & 1 & 1 & 1 \\
\hline 12 & SITI & 1 & 1 & 1 & 0 & 0 & 0 & 1 & 0 \\
\hline 13 & YATI & 1 & 1 & 1 & 1 & 1 & 1 & 1 & 0 \\
\hline & & 13 & 13 & 13 & 10 & 9 & 11 & 13 & 6 \\
\hline
\end{tabular}


Table 5.4 Persentase Pengetahuan Responden setalah latihan

\begin{tabular}{|c|c|c|}
\hline Item Pertanyaan & Total jawab "ya" & (\%) jawaban "ya" \\
\hline P1 & 13 & 100 \\
\hline P2 & 13 & 100 \\
\hline P3 & 13 & 100 \\
\hline P4 & 10 & 76,92 \\
\hline P5 & 9 & 69,23 \\
\hline P6 & 11 & 84,61 \\
\hline P7 & 13 & 100 \\
\hline P8 & 6 & 46,15 \\
\hline Total & 88 & 676,91 \\
\hline Rata-Rata & 11 & 84,61 \\
\hline
\end{tabular}

Untuk mengetahui posisi persentasi jawaban "ya" yang diperoleh dari angket maka dihitung terlebih dahulu, kemudian ditempatkan dalam rentang skala persentase sebagai berikut:

Nilai jawaban "ya" $\quad: 1$

Nilai jawaban "tidak" : : :

Dikonversikan kedalam persentase:

Jawaban "ya" 1x100\% : 100\%

Jawaban "tidak" : $\quad$ : $\quad$ (sehingga tidak perlu dihitung)

Perhitungan jawaban "ya" dari angket:

Jawaban "ya" rata-rata : $84,61 \%$

Jadi pengeahuan responden $\quad: 84,36-12,5=71,86$

\section{KESIMPULAN}

Kesimpulan harus mengindikasi secara jelas hasil-hasil yang diperoleh, kelebihan dan kekurangannya, serta kemungkinan pengembangan selanjutnya.

Kesimpulan dapat berupa paragraf, namun sebaiknya berbentuk point-point dengan menggunakan numbering atau bullet.

Hasil dari evaluasi yang dilakukan berdasarkan kuisioner yang diberikan kepada peserta, maka diperoleh kesimpulan bahwa kegiatan pelatihan yang dilaksanakan sesuai dengan tujuan yang ingin dicapai yaitu meningkatkan pengetahuan dan kemampuan peserta dalam pemanfaatan aplikasi Baby Care, sehingga sosialisasi ini diharapkan betul-betul dapat menggantikan proses sebelumnya yang pencatatannya masih dilakukan secara manua dan rawan Human Eror.

\section{SARAN}

Mengingat banyaknya manfaat aplikasi Baby Care ini diharapkan kedepannya:

1. Perlunya perluasan target peserta dalam mengikuti kegiatan pelatihan

2. Diharapkan adanya pengembangan aplikasi missal dalam memberikan alarm sebagai pengingat jadwal vaksin berikutnya.

\section{UCAPAN TERIMA KASIH}

Penulis mengucapkan terima kasih kepada Allah Subhanahu Wa Ta'ala atas Rahmad dan Hidayah Nya sehingga terselesainya pengabdian ini. Kemudian terimakasih saya ucapkan kepada Fakultas Ilmu Komputer Universitas Lancang Kuning atas dukungan financial terhadap pengabdian ini. 


\section{DAFTAR PUSTAKA}

[1] Putra, Sari, Suhatman, 2012. Aplikasi Pembelajaran Metamorfosis Berbasis Android Augmented Reality. Jurnal Aksara Komputer Terapan, Volume 1, Nomor 1, 2012.

[2] Martono, Kridalukmana, 2014. Mobile Augmented Reality Jurusan Sistem Komputer Universitas Diponegoro Berbasis Android (MARSISKOM). Jurnal Sistem Komputer, volume 4, nomor 1

[3] Application Fundamentals. Android Developers. 2012. Android, Inc. 22 September 2012.

[4] Stan Z. Li, Anil K. Jain, "Handbook of Face Recognition" Springer, 2005.

[5] Sessa,Carloss 2013. 50 Android Hacks, Manning Publication. 